\title{
КРИМІНАЛЬНО-ПРАВОВИЙ ЗАХИСТ ТЕРИТОРІАЛЬНОЇ ЦІЛІСНОСТІ ТА НЕДОТОРКАНОСТІ ДЕРЖАВИ ЯК СКЛАДОВА ЧАСТИНА КОНСТИТУЦІЙНОГО ЛАДУ
}

Швед А. Ю.

Метою статті стало дослідження на підставі аналізу національного та міжнародного законодавства, а також міжнародної судової практики питання кримінально-правового захисту територіальної цілісності та недоторканості держави, як складової частини конституційного ладу. Автором було встановлено, що в законодавстві України легального визначення поняттям «територіальна цілісність» та «територіальна недоторканість» не дається, в зв'язкуз зим було досліджено семантику вказаних понять, встановлено їх співвідношення та відмінність. Визначено, що як об'єкти кримінально-правової охорони територіальна цілісність та недоторканість закріплені в положеннях статmі 110 КК України. Також автором було встановлено, що, вирішуючи питання про настання відповідальності за порушення територіальної цілісності та недоторканості, не менш важливим $\epsilon$ питання визначення способу такого порушення.

Проаналізувавши міжнародні нормативно-правові акти, автор встановив, що розрізняють пряме та непряме порушення територіальної цілісності та недоторканості. Встановлено, що у випадку застосування прямого способу відбувається застосування збройної сили державою-порушником проти суверенітету, територіальної недоторканності або політичної незалежності іншої держави. Розглянуто форми агресії, вчинення яких державою-порушником безпосередньо або шляхом використання нерегулярних бойовиків буде розглядатись як прямий спосіб. Також автором було досліджено дії держав-порушників або недержавних суб'єктів, які відповідно до норм міжнародного права належать до непрямих способів порушення територіальної цілісності та недоторкаHOCMi.

За результатами проведених досліджень автором було сформульовано пропозиції щодо вдосконалення положень чинного Кримінального кодексу України у сфері кримінально-правового захисту територіальної цілісності та недоторканості держави як складової частини конституційного ладу.

Ключові слова: територіальна чілісність, територіальна недоторканість, конституційний лад, кримінально-правова охорона, способи захисту.

(с) Швед А. Ю., 2020
Shved A. Yu. Criminal legal protection of territorial integrity and inviolability of the state as an integral part of the constitutional order

The purpose of the article was to study on the basis of the analysis of national and international legislation, as well as international judicial practice the issue of criminal protection of territorial integrity and inviolability of the state as part of the constitutional order. The author found that the legislation of Ukraine does not give a legal definition of the concept of "territorial integrity" and "territorial integrity", in connection with which the semantics of these concepts were studied, their relationships and differences were established. It is determined that as objects of criminal law protection territorial integrity and inviolability are enshrined in the provisions of Article 110 of the Criminal Code of Ukraine. The author also found that in deciding on the occurrence of liability for violation of territorial integrity and inviolability is no less important to determine the method of such violation. After analyzing international regulations, the author found that distinguish between direct and indirect violations of territorial integrity and inviolability. It is established that in the case of the use of the direct method, the violating state uses armed force against the sovereignty, territorial integrity or political independence of another state. Forms of aggression committed by the offending state directly or through the use of irregular militants will be considered as a direct method. The author also studied the actions of violating states or non-state actors, which, in accordance with international law, belong to the indirect ways of violating territorial integrity and inviolability. Based on the results of the research, the author formulated proposals to improve the provisions of the current Criminal Code of Ukraine in the field of criminal protection of territorial integrity and inviolability of the state as part of the constitutional order.

Key words: territorial integrity, territorial inviolability, constitutional order, criminal law protection, methods of protection.

Постановка проблеми та іï актуальність. Говорячи про конфлікт між Російською Федерацією та Україною, поверхневим $\epsilon$ саме спір щодо контролю над територіями. Захист територіальної 
цілісності належить до основних принципів міжнародного права i в поєднанні із забороною застосування сили, є однією з основних задач Організації Об'єднаних націй щодо забезпечення міжнародного миру і стабільності. Така юридична концепція з першого погляду є безперечною, але проблеми виникають на рівні застосування принципу до конкретних ситуацій, i, на жаль, яскравим прикладом є ситуація на території нашої країни.

Аналіз досліджень і публікацій. Вказана проблематика неодноразово була об'єктом наукових досліджень, зокрема питання кримінально-правової охорони конституційного ладу, територіальної цілісності та недоторканості розглядалась прямо чи опосередковано в роботах таких вчених, як П.П. Андрушко, О.Ф. Бантишев, В.С. Батригареєва, В.О. Глушков, О.О. Гречко, І.В. Діордіца, О.О. Дудоров, І.В. Зозуля, Д.С. Зоренко, М.Й. Коржанський, В.А. Ліпкан, П.С. Матишевський, В.А. Мисливий, Л.В. Мошняг, В.О. Навроцький, Д.О. Олєйніков, М.І. Панов, О.О. Рєзнікова, М.А. Рубащенко, О.П. Рябчинська, Є.Д. Скулиш, В.В. Тацій, В.Я. Томчук, Є.В. Фесенко, П.Л. Фріс, М.І. Хавронюк, Є.І. Харитонов, Р.Л. Чорний, О.А. Чуваков, О.В. Шамара, С.С. Яценко, А.М. Ященко та деяких інших вчених.

Мета статті полягає у дослідженні на підставі аналізу національного та міжнародного законодавства, а також міжнародної судової практики питання кримінально-правового захисту територіальної цілісності та недоторканості держави, як складової частини конституційного ладу.

Виклад основного матеріалу. Територія $\epsilon$ основною ознакою кожної суверенної держави. За словами французького вченого Л. Дюгі: «Колективність може бути державою тільки тоді, коли вона осіла не території з визначеними кордонами. Без цього немає держави». «...виключна приналежність території однієї колективності $\epsilon$ необхідною для існування держави і саме тому, що в інакшому випадку колективність не змогла б мати в своєму розпорядженні політичної влади» [1, с. 128-131]. Також у своїй роботі автор доходить висновку про неподільність території, оскільки остання $\epsilon$ елементом особистості держави, а будь-яка особистість $є$ цілісною та неподільною.

Основним законом нашої країни встановлено, що Україна $\epsilon$ суверенна i незалежна, демократична, соціальна, правова держава (стаття 1), $\epsilon$ унітарною державою, яка в межах існуючого кордону $\epsilon$ цілісною та недоторканою (стаття 2), $\epsilon$ республікою, а носієм суверенітету та єдиним джерелом влади в Україні $\epsilon$ народ (стаття 5), захист суверенітету і територіальної цілісності України, забезпечення іï економічної та інформаційної безпеки $є$ найважливішими функціями держави, справою всього Українського народу (стаття 17), відповідно до статті 73 Конституції України виключно всеукраїнським референдумом вирішуються питання про зміну території України, а положеннями ст. 132 Конституції України встановлено, що територіальний устрій України ґрунтується на засадах єдності та цілісності державної території, поєднання централізації і децентралізації у здійсненні державної влади, збалансованості і соціально-економічного розвитку регіонів, з урахуванням їх історичних, економічних, екологічних, географічних і демографічних особливостей, етнічних і культурних традицій [2]. Вказані положення дають досить вичерпну характеристику української державності та формують уявлення про основні риси України як держави. Розділом I Декларації про суверенітет, який дістав назву «Самовизначення української нації» встановлено, що Українська РСР як суверенна національна держава розвивається в існуючих кордонах на основі здійснення українською нацією свого невід'ємного права на самовизначення [3].

Про захист територіальної цілісності, який визначено найважливішим компонентом заборони застосування сили йдеться і у статті 2 Статуту Організації Об'єднаних Націй, пунктом 4 якої встановлено, що всі члени Організації Об'єднаних Націй мають утримуватись в міжнародних відносинах від погрози силою або їі застосування як проти територіальної недоторканості або політичної незалежності будь-якої держави, так і будьяким іншим способом, який не сумісний з Цілями Об'єднаних Націй [4]. Після прийняття Статуту ООН в 1945 році концепція територіальної цілісності знайшла своє відображення у великій кількості нормативних документів, таких як Резолюції ООН, наприклад, від 24 жовтня 1970 року № 2625 (XXV) про затвердження Декларації про принципи міжнародного права, що стосуються дружніх відносин та співпраці між державами, та № 3314 (XXIX) від 14 грудня 1974 року Про визначення агресії, а також багатосторонніх та двосторонніх угодах: Конвенції ООН з морського права, Римському статуті міжнародного кримінального суду. Та особливе значення для міжнародних зобов'язань між Україною та Росією має Будапештський меморандум 1994 року, відповідно до якого внаслідок відмови від ядерної зброї Україна отримує від Російської Федерації, Сполученого Королівства 
Великої Британії та Північної Ірландії та Сполучених Штатів Америки підтвердження зобов'язання згідно з принципами Заключного акту НБСЕ поважати незалежність, суверенітет та існуючі кордони України [5]. Хоча російські політики та навіть окремі науковці - фахівці з міжнародного права та міжнародних відносин - намагаються виправдовувати агресивні дії В. Путіна. Вони стверджують: «Оскільки Будапештський меморандум не ратифікувала жодна зі сторін-підписантів, документ «не пройшов процес надання йому юридичної сили через відповідні парламентські процедури", що надає Росії «реальну правову відмовку». Вона нібито не має відповідних зобов'язань, а сам Меморандум можна вважати юридично нікчемним [6, с. 25]. Однак, безумовно, однозначне та беззаперечне юридичне зобов'язання міститься в Договорі про дружбу, співробітництво і партнерство між Україною та Російською Федерацією, який було ратифіковано Законом № 13/98-ВР від 14.01.98 р., статтею 2 якого закріплено, що Високі Договірні Сторони як дружні, рівноправні і суверенні держави засновують свої відносини на взаємній повазі та довірі, стратегічному партнерстві та співробітництві [7].

Захист територіальної цілісності держави покликаний гарантувати іï подальше існування у визначених та встановлених кордонах і робить односторонні зміни території силовими засобами третіх держав порушенням міжнародного права. Та в цьому разі, на нашу думку, йдеться не тільки про територію та захист кордону між державами, аналіз змісту міжнародного законодавства свідчить про нерозривне поєднання понять територіальної цілісності та недоторканості з поняттям політичної незалежності.

Державна політика у сферах національної безпеки і оборони спрямована на захист: держави - іiі конституційного ладу, суверенітету, територіальної цілісності та недоторканності, а державний суверенітет та територіальна цілісність віднесені до фундаментальних національних інтересів [8]. Вказані національні інтереси забезпечують саме існування українського народу, ідентифікує його та реалізує право на розвиток у відповідному просторі демократичної, незалежної, суверенної, правової та соціальної держави.

Беручи до уваги вищевказані конституційні принципи та положення міжнародного права, Особливою частиною Кримінального кодексу України було встановлено відповідальність за вчинення протиправних діянь, які спрямовані на порушення територіальної цілісності та недоторканості держави.
У якості самостійних об'єктів кримінально-правової охорони територіальна цілісність та недоторканість виступають відповідно до положень статті 110 КК України, а також як складова частина конституційного ладу, кримінальна охорона якого відповідно до положень частини першої статті 1 КК України відноситься до основних завдань Кримінального кодексу України [9].

У національному законодавстві України легального визначення поняттям «територіальна цілісність» та «територіальна недоторканість» не дається. На думку Л.В. Мошняги: «Територіальна цілісність $\epsilon$ широким поняттям, яке містить у собі, окрім іншого, територіальну недоторканість... Отже, у міжнародних правових актах територіальна недоторканність вважається складовою частиною територіальної цілісності» [10, ст. 80-83]. Така позиція виглядає достатньо дискусійною, тому що відповідно до тексту Юридичної енциклопедії: Цілісність та недоторканість території держави - один з загальновизнаних принципів сучасного міжнародного права. Недоторканість зумовлює насамперед заборону будь-якого посягання однієї держави на територію іншої. Цілісність означає неприпустимість насильницького розчленування території або захоплення та відторгнення (анексії) їі частини [11, ст. 442]. 3 цілком об'єктивного визначення О.О. Гречко, вбачається, що цілісність і недоторканість не $\epsilon$ синонімами: цілісність означає внутрішню єдність, а недоторканість передбачає гарантованість від зовнішніх зазіхань [12, ст. 13]. Вказане дає нам підстави вважати, що територіальну цілісність та територіальну недоторканість сукупно слід розглядати як характеристику території держави як соціальної цінності. Дійсне порушення недоторканості території держави дістає свій вираз в порушенні вказаних зовнішніх умов та може мати наслідки у вигляді суспільно-небезпечних наслідків для території держави, зокрема, порушення територіальної цілісності. Отже, територіальна цілісність $€$ складовою частиною більш широкого поняття - територіальної недоторканості, тобто стану, коли територія держави $є$ захищеною від будь-яких посягань, в тому числі протиправних посягань, які можуть завдавати шкоди єдності та неподільності території або ж створювати умови, за яких може виникнути загроза завдання такої шкоди.

Таким чином, виступаючи у якості фундаментальних національних інтересів і територіальна недоторканість, і територіальна цілісність забезпечують основи існування України та вимагають особливого кримінально-правового захисту. 
При вирішенні питання про настання відповідальності за порушення територіальної цілісності та недоторканості не менш важливим $€$ питання визначення способу такого порушення. Розрізняють пряме та непряме порушення територіальної цілісності та недоторканості. Як пряме слід розглядати порушення міжнародного права державою, яка застосовує силу у відношенні іншої держави. Застосовування силових методів має бути «прямо» пов'язаним 3 державою-порушником, тобто такі дії мають вчинятись її органами, переважно військовими і мають бути актуальними. Характерним для таких суб'єктів має бути те, що вони $€$ залежними від держави та у відповідності до її внутрішніх законів. Також як прямий спосіб можна розглядати випадки, коли держава агресор скеровує у відношенні іншої держави нерегулярних бойовиків, наприклад, таких, як так звані ополченці або збройні формування, які діють під ефективним контролем та керівництвом держави-нападника, на відміну від державних органів, такий контроль не вимагає повної залежності суб'єктів та не потребує підпорядкування внутрішньому законодавству такої країни. Міжнародним Судом ООН встановлено, що у такому разі держава повинна мати спрямовуючий вплив при вчиненні відповідних силових дій, які здійснюються нерегулярними бойовиками. Так, у своєму Рішенні у справі Боснія та Герцеговина проти Сербії та Чорногорії від 26 лютого 2007 року Міжнародний Суд ООН постановив, що «для визначення того, чи можна прирівнювати особу чи організацію до державного органу, навіть якщо він не має такого статусу згідно із внутрішнім законодавством. По-перше, у цьому контексті немає необхідності доводити, що особи, які вчинили дії, які, як стверджується, порушили міжнародне право, взагалі перебували у відносинах «повної залежності» від держави-відповідача; має бути доведено, що вони діяли відповідно до вказівок цієї держави або під іï «ефективним контролем». Однак слід також довести факт того, що цей «ефективний контроль» був здійснений або що державою надавались вказівки щодо кожної операції, в якій мали місце передбачувані порушення, а не в цілому щодо загальних дій, здійснених особами або групами осіб, що скоїли порушення» [13].

Більш точне розуміння, які саме дії можна вважати прямими способами впливу на територіальну цілісність та недоторканість, можна скласти, проаналізувавши текст документу «Визначення агресії», затвердженого резолюцією 3314 Генеральної Асамблеї ООН від 14 грудня 1974 року. Так, відпо- відно до статті 3 вказаного документу як акт агресії слід розглядати: а) вторгнення або напад збройних сил держави на територію іншої держави або будь-яку військову окупацію, який би тимчасовий характер вона не мала, що $\epsilon$ результатом такого вторгнення або нападу, або будь-яка анексія із застосуванням сили території іншої держави або частини iï; b) бомбардування збройними силами держави території іншої держави або застосування будь-якої зброї державою проти території іншої держави; с) блокада портів або берегів держави збройними силами іншої держави; d) напад збройними силами держави на сухопутні, морські або повітряні сили, або морські і повітряні флоти іншої держави; е) застосування збройних сил однієї держави, що знаходяться на території іншої держави за згодою з приймаючої держави, в порушення умов, передбачених в угоді, або будь-яке продовження їх перебування на такій території по припиненню дії угоди; (вказане положення $\epsilon$ досить актуальним у розрізі використання Російською Федерацією для вчинення дій з анексії території АР Крим своїх військових формувань, які знаходились на півострові на підставі Угоди про базування Чорноморського флоту РФ на території України - виділено автором А.Ш.) f) дії держави, що дозволяє, щоб іï територію, яку вона надала в розпорядження іншої держави, було використано цією іншою державою для здійснення акту агресії проти третьої держави; g) засилання державою або від імені держави збройних банд, груп, іррегулярних сил або найманців, які здійснюють акти застосування збройної сили проти іншої держави, що мають настільки серйозний характер, що це рівносильне перерахованим вище актам, або його значну участь в них [14]. Використання військових формувань, зброї та військової техніки РФ при анексії АР Крим та окупації частини територій Донецької та Луганської областей дають всі підстави для того, щоб говорити про прямий спосіб порушення територіальної цілісності та недоторканості України.

Другий тип порушень - непрямі. До таких непрямих порушень слід віднести випадки, коли фактична військова діяльність проти територіальної цілісності та недоторканості не $\epsilon$ такою, що пов'язана з певною державою, оскільки така потенційна держава-агресор не використовувала для застосування сили свої державні органи, а також прямо не надсилала та не контролювала нерегулярних бойовиків Порівняно з прямими порушеннями, які зазвичай становлять збройний напад, Міжнародний Суд ООН описує ці непрямі 
форми як «менш важкі форми застосування сили», хоча вони також $\epsilon$ забороненими. Так, у справі про військову та невійськову діяльність в Нікарагуа - Military and Paramilitary Activities in and against Nicaragua, I.C.J. Reports 1986, було розглянуто чи має бути притягнуто до відповідальності Сполучені Штати Америки за поведінку нікорагуанського віськово-політичного руху «Контрас», та чи має США нести загальну відповідальність за скоєні бойовиками порушення міжнародного гуманітарного права. Дії США були розглянуті Міжнародним Судом з точки зору «контролю» над діями бойовиків. Судом встановлено та визнано, що підготовка, озброєння, спорядження, фінансування і постачання або будь-яка інша допомога, вчинена США у відношенні «Контрас», $є$ порушенням принципу невтручання у внутрішні справи. Проте США було відмовлено в задоволенні вимоги Нікарагуа про покладення на США відповідальності за всі дії, вчинені «Контрас» на їі території, основним аргументом в позиції Міжнародного суду стало те, що Сполучені Штати Америки не здійснювали повного контролю над бойовиками, і тому не можна вважати, що останні діяли від їх імені [15].

У випадку з Україною та агресією щодо неї з боку Російської Федерації нам конче необхідно врахувати вищенаведену міжнародну практику. Якщо у відношенні анексії AP Крим все ж таки президентом РФ в інтерв'ю було визнано, що російські війська зіграли вирішальну роль в Криму, а саме: «сили самооборони Криму, звичайно, підтримували російські військові», він апелює до обставин, застосування яких була необхідною «для захисту людей навіть від найменшої можливості використання зброї проти цивільного населення» [16].

Висновки. У разі з окупацією територій в Донецькій та Луганській областях Російська Федерація наполягає на позиції повної непричетності та відсутності воєнної підтримки ополченців та бойовиків. В такому разі, виходячи з міжнародної практики, хоча держава-правопорушник порушує територіальну цілісність держави-жертви, надаючи підтримку повстанцям, вона не здійснює достатнього ступеня контролю, щоб розглядати застосування сили третіми групами як збройний напад такою державою і в такому разі норми міжнародного законодавства не діють, а всі питання мають вирішуватися відповідно до внутрішнього законодавства держави. Тому необхідність у належній кримінально-правовій охороні фундаментальних національних інтересів $є$ для України не просто потребою не відставати від тенденцій та глобальних змін у світі, а нагальною потребою в збереженні суверенітету та незалежності, та недопущенні уникнення відповідальності особами, які вчиняють дії, спрямовані на порушення демократичного конституційного ладу в нашій державі.

На підставі викладеного автором пропонуються наступні зміни до положень Кримінального кодексу України: з огляду на неоднаковий розгляд законодавцем питання щодо способу вчинення дій, передбачених в статтях 109 та 110 КК України, який $є$ досить важливим з декількох підстав, по-перше, його відсутність в тексті статті $110 \mathrm{KK}$ дає підстави вважати, що спосіб (насильницький або не насильницький) не $є$ обов'язковим елементом складу злочину, а центром всього виступає саме поняття територія України і в такий спосіб законодавцем акцентується увага на їі особливо важливій соціальній цінності. В той же час насильницький спосіб вчинення дій, передбачених частиною 1 статті 110 КК України, значно підвищує ступінь суспільної небезпечності і вчинення зазначених злочинів у такий спосіб посягає не тільки безпосередньо на територіальну недоторканість та державний кордон, а й, наприклад, на життя та здоров'я громадян України. В зв'язку з цим пропонуємо зазначити в статті 110 КК України спосіб, яким може бути вчинено злочини, відповідальність за які передбачена частиною першою вказаної статті, та встановити більш суворе покарання у випадку застосування суб'єктом злочину насильницьких дій.

Крім того, в частині третій статті 110 КК України має бути більш точно відображено наявність таких тяжких наслідків, таких як порушення територіальної цілісності України, яке може бути виражено у відторгненні всієї території або будь-якої іï частини на порушення порядку, встановленого Конституцією України, тобто шляхом встановлення верховенства над такою територією без згоди українського народу, вираженої на всеукраїнському референдумі. Таким чином, вважаємо за необхідне доповнити частину третю статті $110 \mathrm{KK}$ України положеннями про «дії, які призвели до втрати всієї території України або будь-якої їі частини, або позбавлення прав на вказані території, або інші тяжкі наслідки». В такому разі під тяжкими наслідками можна розуміти ті реалії, з якими довелося стикнутися нашій державі, у вигляді: тимчасової окупації (захоплення) території України або їі частини, приведення території України в непридатний для життєдіяльності стан тощо. 


\section{Література}

1. Дюги Л. Конституционное право. Общая теория государства. Репринтное воспроизведение издания 1908 года. Одесса : Юрид. літ., 2005. $958 \mathrm{c}$.

2. Конституція України прийнята 28 червня 1996 рокy № 254k/96-BP. URL: https://zakon.rada.gov.ua/ laws/show/254\%D0\%BA/96-\%D0\%B2\%D1\%80\#n4976.

3. Декларація про державний суверенітет України від 16 липня 1990 року № 55-XII. URL: https://zakon.rada.gov.ua/laws/show/55-12.

4. Статут Організації Об'єднаних Націй від 26 червня 1945 року № 995_010. URL: https:// zakon.rada.gov.ua/laws/show/995_010\#Text.

5. Меморандум про гарантії безпеки у зв'язку 3 приєднанням України до Договору про нерозповсюдження ядерної зброї від 05 грудня 1994 року №998_158. URL: https://zakon.rada.gov.ua/laws/ show/998_158\#Text.

6. Лоссовський І. Міжнародно-правовий статус Будапештського меморандуму: договір, обов'язковий для виконання всіма його сторонами: монографія. Київ: Українська асоціація зовнішньої політики, 2015. 124 c.

7. Договір про дружбу, співробітництво і партнерство між Україною і Російською Федерацією від 31.05.1997 року ратифікований Законом України від 14.01.1998 року № 13/98-ВР, припинення дії на підставі Закону України «Про припинення дії Договору про дружбу, співробітництво і партнерство між Україною і Російською Федерацією» від 01.04.2019 року № 2643-VIII, URL: https://zakon.rada.gov.ua/laws/ show/643_006\#Text.

8. Стратегія національної безпеки України «Безпека людини - безпека країни» затверджена Указом Президента України від 14 вересня 2020 року № 392/2020. URL: https://www.president.gov.ua/ documents/3922020-35037.

9. Кримінальний кодекс України від 05.04.2001 № 2341-III. URL: https://zakon.rada.gov.ua/laws/ show/2341-14.
Протидія злочинності: проблеми практики та науково-методичне забезпечення

10. Мошняга Л.В. Кримінальна відповідальність за злочини проти конституційних основ національної безпеки України : дис. ... канд. юрид. наук : 12.00.08 «Кримінальне право та кримінологія; кримінальновиконавче право»/ ХНУВС. Харків, 2011. 226 с.

11. Юридична енциклопедія: у 6 т. / Редкол.: Ю.С. Шемшученко (голова редкол.) та ін. Київ: «Укр. Енцикл.», 1998 р., Т. 6. Т-Я. 2004. 768 с.

12. Гречко О.О. Принцип єдності та цілісності державної території як гарантія унітарного характеру української держави. Право і Безпека. 2014. вип.№ 4 (55). с. 12-15.

13. Application of the Convention on the Prevention and Punishment of the Crime of Genocide (Bosnia and Herzegovina v. Serbia and Montenegro), Judgment, I.C.J. Reports2007, p. 43. Cour internationale de Justice: веб-сайт. URL: https://www.google.com/url?sa=t\&r $c t=j \notin q=\&$ \&resc $=s \&$ source $=w e b \& c d=\& v e d=2$ ahUKEwizq NX28ofvAhXEK3cKHR_7CUcQFjABegQIAhAD\&url=https $\% 3 \mathrm{~A} \% 2 \mathrm{~F} \% 2 \mathrm{Fwww}$.icj-cij.org\%2Fpublic\%2Ffiles\%2Fcaserelated\%2F91\%2F091-20070226-JUD-01-00-EN. pdf\&usg=AOvVaw3mEvKOEG-557qaTr7i1nl5.

14. «Визначення агресії» затвердженого резолюцією № 3314 Генеральної Асамблеї ООН від 14 грудня 1974 року № 995_001-74, URL: https:// zakon.rada.gov.ua/laws/show/995_001-74\#Text.

15. Paramilitary Activities in and against Nicaragua Nicaragua v. United States of America). Judgment of 27 June 1986 // I.C.J. Reports 1986. Cour internationale de Justice: веб-сайт. URL: https:// www.icj-cij.org/en/case/70/judgments.

16. RT, Putin Acknowledges Russian Military Serviceman Were In Crimea, 17.4.2014, published together with a video documentation of Putin's statements with simultaneous translation into English at. RT : веб-сайт. URL: http: //www.rt.com.

Швед А. Ю., здобувач кафедри кримінального права, кримінології цивільного та господарського права ВН3 «Національна академія управління» 